\title{
Final height after gonadotropin-releasing hormone agonists with or without growth hormone in Korean girls with central precocious puberty and early puberty
}

\author{
Eun Byul Kwon*, Young Suk Shim, Hae Sang Lee, Hwal Rim Jeong, Jin Soon Hwang
}

From 8th APPES Biennial Scientific Meeting

Darwin, Australia. 29 October - 1 November 2014

\section{Aims}

We investigated the final height (FH) in GnRHa treatment with or without $\mathrm{GH}$ in Korean girls with $\mathrm{CPP}$ or EP.

\section{Methods}

The forty-one patients were divided retrospectively into three groups: group 1 subjects with CPP $(n=20)$ received GnRHa. Group 2 with early puberty $(n=12)$ received only GnRHa. Group 3 with early puberty $(n=9)$ received combined treatment with $\mathrm{GH}$ and GnRHa.

\section{Results}

The mean age at the start of treatment was $8.11 \pm 0.70$ years in group 1, $8.98 \pm 0.38$ years in group 2 and $9.46 \pm$ 0.46 years in group 3 , respectively. The mean predicted adult height (PAH) SDS at the start of treatment was $-1.29 \pm 1.16$ in group $1,-1.14 \pm 0.88$ in group 2 and $-1.87 \pm 1.09$ in group 3, respectively. Rate of growth during treatment with GnRHa combined with GH was higher significantly in group $3(6.89 \pm 1.45 \mathrm{~cm})$ than in group 1 $(5.27 \pm 0.89 \mathrm{~cm}, \mathrm{p}=0.001)$ and in group $2(5.64 \pm 0.72$ $\mathrm{cm}, \mathrm{p}=0.022)$. The mean FH SDS was $-0.60 \pm 0.88$ in group $1,-0.40 \pm 1.03$ in group 2 and $-0.92 \pm 0.72$, respectively and significantly higher than initial height prediction. For the girls received GnRHa alone, FH SDS was correlated significantly with TH SDS, PAH at the start of treatment, $\mathrm{PAH}$ at the discontinuation of treatment.

Department of Pediatrics, Ajou University Hospital, School of Medicine, Ajou University, Suwon, Korea

\section{Conclusion}

After GnRHa treatment in girls with CPP or EP, FH is significantly higher than initial height prediction. GnRHa treatment combined with GH resulted in higher growth rate.

Published: 28 April 2015

doi:10.1186/1687-9856-2015-S1-P95

Cite this article as: Kwon et al:: Final height after gonadotropinreleasing hormone agonists with or without growth hormone in Korean girls with central precocious puberty and early puberty. International Journal of Pediatric Endocrinology 2015 2015(Suppl 1):P95.
Submit your next manuscript to BioMed Central and take full advantage of:

- Convenient online submission

- Thorough peer review

- No space constraints or color figure charges

- Immediate publication on acceptance

- Inclusion in PubMed, CAS, Scopus and Google Scholar

- Research which is freely available for redistribution

Submit your manuscript at www.biomedcentral.com/submit
() Biomed Central 